\title{
Antipyretic Activity of The Aqueous Extract of Cumin (Cuminum cyminum L.) with Yeast Induced Pyrexia in Female Rats.
}

\author{
Awatif M. Al-Saaedi \\ University of Thi-Qar/ College of Science/ Biology Department \\ Thi-Qar/ Iraq \\ e-mail: awatifhistology_bio@sci.utq.edu.iq
}

\author{
Ihsan Hameed khudhair \\ University of Thi-Qar/ College of Science/ Biology Department \\ Thi-Qar/ Iraq \\ e-mail: \\ ehsan1981hameed@sci.utq.edu.iq
}

https://doi.org/10.32792/utq/utjsci/v8/1/5

\begin{abstract}
Cumin (Cuminum cyminum L.) is one of the important aromatic plants that is used as an antipyretic in folk medicine. This study aims to evaluate the antipyretic activity of the aqueous extract $C$. cyminum seeds using the brewer's yeast induced pyrexia method in female rats. Twenty-five adult female rats were divided into five groups $(n=5)$. The first was normal control that only orally received $1 \mathrm{ml}$ of distilled water. Pyrexia was induced in the remaining groups by injection of $30 \%$ yeast suspension $(10 \mathrm{mg} / \mathrm{kg})$. Two groups of the pyretic animals were set as negative control and positive control groups that were orally treated with $1 \mathrm{ml}$ of distilled water and intraperitoneal injected with Aspirin $100 \mathrm{mg} / \mathrm{kg}$, respectively. The fourth and fifth groups were orally received 200 and $400 \mathrm{mg} / \mathrm{kg}$ of the aqueous extract of $C$. cyminum seeds, respectively. Rectal temperature was significantly $(P \leq 0.05)$ decreased in the animal groups treated with Aspirin and C. cyminum extract at both doses when it was measured after $1 \mathrm{~h}$. of drug administration.
\end{abstract}

\section{Keywords-Cumin, Cuminum cyminum, antipyretic}

\section{INTRODUCTION}

The term fever or pyrexia means that the temperature of the body is higher than the normal value due to the hypothalamic rise in set-point temperature (Anochie, 2013).

According to body temperature, animal species are classified into homoeothermic and poikilothermic animals. Homoeothermic animals include mammals and birds that can regulate their body temperature relatively stable despite the surrounding temperature fluctuations. The heat exchange between the homoeothermic animals and their surroundings is regulated by the thermoregulatory center (SchmidtNielsen, 1997; Rastogi, 2001).

Fever originates from different factors, including microbial infections such as enteric fever, seasonal variations, and physiological stress, such as exercise and increasing thyroid secretion (Meller et al., 2007; Vasundra and Divya, 2013).
Herbal medicine takes on considerable significance in primary health care. More than $75 \%$ of the human population depends on medicinal plant extracts, and more than $30 \%$ of known plant species is reserved for therapeutic use. WHO supports the use of herbal treatments that have been proven to be effective in primary health care (Ayon et al., 2014).

Cumin (Cuminum cyminum L.) is one of the important aromatic plants from the Apiaceae family that is widely used as a food additive for fragrance or medicinal preparations. Cumin seeds are used in herbal medicine for treating toothache, dyspepsia, diarrhea, and jaundice (Bhat et al., 2014).

The finding of safe, potent antipyretics from herbal origin received considerable attention recently. Available antipyretic drugs such as nimesulide and paracetamol have a toxic side effect to different organs. In folk medicine, $C$. cyminum seeds are used as antipyretic cure (Begum et al., 2011)

The antipyretic activity of this plant seeds is not well investigated. The present study aims to evaluate the antipyretic effect of aqueous extract of $C$. cyminum seeds

\section{MATERIALS AND METHODS}

\section{A. Plant collection}

Dried C. cyminum seeds were collected from the local markets in Nasiriyah City, Thi-Qar Province, south of Iraq. The seeds were authenticated as C. cyminum according to (Heywood et al., 2007) in University of Basrah/ College of Science. The seeds were ground for further extraction.

\section{B. Plant extraction}

Twenty-five grams of $C$. cyminum seed powder was extracted using a stirrer hot plate with $200 \mathrm{ml}$ of distilled water for 8 hours. The extract was left to stand and was 
filtered into Whatman No.1 filter papers. The extract was concentrated by rotary evaporator and sterilized through a Millipore filter $(0.22 \mu \mathrm{m})$ and left to dry in a sterilized space at room temperature; then, it was stored in dry clean vials at $4^{\circ} \mathrm{C}$ (Harborne, 1984).

\section{Experimental animals}

Twenty-five adult female rats were purchased from University Of Al-Qadisiyah/ College of Veterinary Medicine. The rats were maintained at $20^{\circ} \mathrm{C} \pm 2{ }^{\circ} \mathrm{C}$ with a day/night cycle of 12 hours and access to water and water ad libitum.

\section{Antipyretic activity}

C. cyminum seed extract was evaluated for antipyretic effect by yeast-induced pyrexia test according to (Vasundra and Divya, 2013) with some modifications. Animals were randomly divided into five groups $(n=5)$ and treated as follows:

Group (1): Orally received $1 \mathrm{ml}$ of distilled water (normal control).

Group (2): subcutaneously injected with $30 \%(10 \mathrm{ml} / \mathrm{kg})$ of brewer's yeast suspension and orally administrated $1 \mathrm{ml}$ of distilled water (negative control).

Group (3): served as positive control that was subcutaneously injected with $30 \%(10 \mathrm{ml} / \mathrm{kg})$ of brewer's yeast suspension and intraperitoneal injected with $100 \mathrm{mg} / \mathrm{kg}$ of acetylsalicylic acid (Aspirin).

Group (4): subcutaneously injected with $30 \%(10 \mathrm{ml} / \mathrm{kg})$ of brewer's yeast suspension and orally treated with $200 \mathrm{mg} / \mathrm{kg}$ of $C$. cyminum seed extract dissolved in $1 \mathrm{ml}$ of distilled water (Experimental group A).

Group (5): subcutaneously injected with $30 \%(10 \mathrm{ml} / \mathrm{kg})$ of brewer's yeast suspension and orally treated with $400 \mathrm{mg} / \mathrm{kg}$ of $C$. cyminum seed extract dissolved in $1 \mathrm{ml}$ of distilled water (Experimental group B).

Injection of $30 \%$ of brewer's yeast suspension $(10 \mathrm{ml} / \mathrm{kg})$ was used for inducing fever. The vehicle, reference drug, and plant extract were administrated after 6 hours of yeast injection. The animals' rectal temperature was measured by the use of a well-lubricated digital thermometer that was inserted into the rectum at the depth $2 \mathrm{~cm}$ at $0,1,2$, and 3 hours after extract and standard drug administration.

\section{E. Statistical analysis}

Results were analyzed by SPSS 26 software using one way ANOVA test and were expressed as Mean \pm SEM. Data was further subjected to LSD test. Differences between groups were considered significant at a level of $\mathrm{P} \leq 0.05$.

\begin{tabular}{|c|c|c|c|c|}
\hline \multirow{2}{*}{ groups } & \multicolumn{4}{|c|}{ Time } \\
\cline { 2 - 5 } & $\mathbf{0 ~ h .}$ & $\mathbf{1} \mathbf{~ h .}$ & $\mathbf{2} \mathbf{~ h .}$ & $\mathbf{3} \mathbf{~ h .}$ \\
\hline $\mathbf{1}$ & $37.46 \pm 0.09^{\mathrm{b}}$ & $37.56 \pm 0.05^{\mathrm{b}}$ & $37.52 \pm 0.08^{\mathrm{b}}$ & $37.46 \pm 0.06^{\mathrm{b}}$ \\
\hline $\mathbf{2}$ & $40.4 \pm 0.5^{\mathrm{a}}$ & $41 \pm 0.44^{\mathrm{a}}$ & $39.74 \pm 0.18^{\mathrm{a}}$ & $39.14 \pm 0.12^{\mathrm{a}}$ \\
\hline $\mathbf{3}$ & $40.6 \pm 0.6^{\mathrm{a}}$ & $37.48 \pm 0.05^{\mathrm{b}}$ & $37.5 \pm 0.05^{\mathrm{b}}$ & $37.4 \pm 0.5^{\mathrm{b}}$ \\
\hline $\mathbf{4}$ & $40.5 \pm 0.3^{\mathrm{a}}$ & $38.1 \pm 0.16 \mathrm{~b}$ & $37.76 \pm 0.58^{\mathrm{b}}$ & $37.58 \pm 0.1^{\mathrm{b}}$ \\
\hline $\mathbf{5}$ & $40.8 \pm 0.37^{\mathrm{a}}$ & $37.76 \pm 0.96^{\mathrm{b}}$ & $37.62 \pm 0.08^{\mathrm{b}}$ & $37.56 \pm 0.12^{\mathrm{b}}$ \\
\hline $\mathbf{L S D}$ & $\mathbf{1 . 1 8}$ & $\mathbf{0 . 6 3}$ & $\mathbf{0 . 3 2}$ & $\mathbf{0 . 2 7}$ \\
\hline
\end{tabular}

\section{RESULTS AND DISCUSSION}

Antipyretic effects of $C$. cyminum seed extract on rectal temperature are presented in (Table:1). Yeast injection markedly increased the rectal temperature. After $1 \mathrm{~h}$. of administration, both of $C$. cyminum seed extract with the two doses (200 and $400 \mathrm{mg} / \mathrm{kg}$ ) and the reference drug appeared a significant $(\mathrm{P} \leq 0.05)$ antipyretic activity. This significant reduction continued over a period from $1 \mathrm{~h}$. to 3 .

TABLE I. : ANTIPYRETIC ACTIVITY OF THE AQUEOUS EXTRACT OF C. CYMINUM SEEDS

Values are means \pm S.E.M. Different letters refer to the significant difference at $\mathrm{P} \leq 0.05$ )

The increase of body temperature happens due to Prostaglandin E2 (PGE2) accumulates in the hypothalamus. The firing rate of hypothalamic neurons is the controller of thermoregulation, and it is altered by increased PGE2 synthesis. Many investigations had shown that inhibiting of cyclooxygenase and consequently decreasing of PGE2 levels in the hypothalamic region are the main action mechanisms of the most antipyretic drugs. However, it is difficult to rule out other mechanisms in pyrexia regulation (Saper et al., 2012; Anochie, 2013).

\section{REFERENCES}

1. Anochie, I. (2013). Mechanisms of fever in humans. Int.J. Microbio. Immunol. Res. 2(5): 37-43.

2. Asaad, G.; Redai, A.; Hakami, A.; Ghazwani, F.; Nomier, Y. and Alshahrani, S. (2020). Potential analgesic and anti-inflammatory effect of Cuminum cyminum and Borago officinalis in rats and mice. Asian $\mathrm{J}$ Pharm Clin Res. 13(1): 216-218.

3. Ayon, B.; Rasmirekha, B.; Divya, A.; Pratap, K.; Sanjay, K. and Sudhanshu, S. (2014). Antipyretic effect of ethanolic extract of Moringa oleifera leaves. Tanta Medical Journal, 42(2):7478.

4. Begum, T. N.; Ilyas, M. H. and Anand, A. V. (2011). Antipyretic activity of azima tetracantha in experimental animals. Int J Cur Biomed Phar Res. 1(2): 41-44.

5. Bhat, S.; Waseem, R. and Anil, K. (2014). Effect of Cuminum cyminum L. Seed Extracts. Journal of Natural Remedies. 14(2): 186-192.

6. Conti, B. (2016). Prostaglandin E2 that triggers fever is synthesized through an endocannabinoid- dependent pathway. Temperature (Austin). 3(1): 25-27.

7. Harborne, J. (1984). Phytochemical Methods. 2nd edition. New York: Chapman and Hall. 
8. Heywood, V.; Brummitt, R.; Culham, A. and Seberg, O. (2007). Flowering Plant Families of the World. Royal Botanic Garden. Kew.

9. Meller, J.; Sahlmann, C. and Scheel, A. (2007). 18F-FDG PET and PET/CT in Fever of Unknown Origin. The journal of nuclear medicine. 1(33-45): 48.

10. Mnif, S. and Aifa, S. (2015). Cumin (Cuminum cyminum L.) from traditional uses to potential biomedical applications. Chemistry \& Biodiversity. 12: 733-742.

11. Niazi, J.; Gupta, V.; Chakarborty, P. and Kumar, P. (2010). Anti-inflammatory and antipyretic activity of Aleuritis moluccana leaves. Asian J Pharm Clin Res. 3: 35-37.

12. Nijveldt, R. J.; Nood, E. V.; Hoorn, D.E.; Boelens, P. G.; Norren, K. V. and Paul, A. L., 2001. Flavonoids: a review of probable mechanisms of action and potential applications. Am J Clin Nutr.74: 418-425.

13. Rastogi, S. (2001). Essentials of animal physiology. 3rd edition. New Delhi: New age international.

14. Reanmongkol, W.; Matsumoto, K.; Watanabe, H.; Subhadhirasakul, S. and Sakai, S. (1994). Antinociceptive and antipyretic effects of alkaloids extracted from the stem bark of Hunteria zeylanica. Biological and Pharmaceutical Bulletin Journal.17(10): 1345-1350.

15. Saper, C. B; Andre, j A. R. and Thomas E. S. (2012). Neural circuitry engaged by prostaglandins during the sickness syndrome. Nature Neuroscience. 15: 1088-1095.

16. Schmidt-Nielsen, K. (1997). Animal physiology: adaptation and environment. 1st Edition ed. Cambridge University Press.

17. Sharma, V.; Kaushik, A.; Dey, Y.; Srivastava, B.; Wanjari, M. and Jaiswal, B. (2020). Analgesic, anti-inflammatory and antipyretic activities of ethanolic extract of stem bark of Anogeissus latifolia Roxb. Clinical Phytoscience 6: 1-9.

18. Soszynski, D. and Krajewska, M. (2002). Lack of tolerance between pyrogenic effects of LPS and turpentine in rats. Journal of Thermal Biology. 27: 229-37
19. Vasundra, D. and Divya, P. (2013). Antipyretic activities of ethanol and aqueous extract of root ofAspargus racemosus in yeast induced pyrexia. Asian J Pharm Clin Res. 6(3): 190-193.

20. Zakaria, Z.; Loo, Y.; Nurul, I.; Abdul, H.; Sulaiman, M and Gopalan , H. (2007). Antinociceptive, Anti-inflammatory and antipyretic properties of the aqueous extract of Bauhinia purpurea leaves in experimental animals. Medical Principles and Practice 16: 443 - 449. 